\title{
PREDIKSI TINGKAT KINERJA STRUKTUR GEDUNG KANTOR BERDASARKAN MUTU BETON DENGAN METODE JARINGAN SARAF TIRUAN
}

\author{
Beny Setiawan \\ Mahasiswa Magister Teknik Sipil Universitas Riau \\ Jalan Subrantas Km 12,5 Pekanbaru, 28293 \\ E-mail : beny.setiawan@student.unri.ac.id \\ Reni Suryanita \\ Magister Teknik Sipil Universitas Riau \\ Jalan Subrantas Km 12,5 Pekanbaru, 28293 \\ E-mail : reni.suryanita@lecturer.unri.ac.id \\ Zulfikar Djauhari \\ Magister Teknik Sipil Universitas Riau \\ Jalan HR. Soebrantas Panam Pekanbaru \\ E-mail : zulfikar.djauhari@ lecturer.unri.ac.id
}

\begin{abstract}
Abstrak
Gempa adalah fenomena alam yang tidak dapat diprediksi kekuatan, kapan dan dimana akan terjadi, fenomena alam ini menjadi salah satu faktor perusak utama bagi wilayahwilayah yang dilewati jalur patahan. Kerugian yang diakibatkan gempa sangat besar, mulai dari kerusakan sarana - prasarana infrastruktur, ekonomi dan juga banyak menelan korban jiwa. Penelitian ini akan dilakukan analisis struktur dengan menggunakan analisis riwayat waktu (time history) dengan bantuan software elemen hingga. Pemodelan berdasarkan struktur bangunan gedung kantor yang direncanakan pada tahun pada tahun 2014, dan standar tingkat kinerja struktur berdasarkan FEMA 356. Pemilihan perencanaan gedung ini dikarenakan perencanaan tersebut tidak memperhitungkan beban gempa dalam analisis strukturnya. Beban gempa yang digunakan adalah gempa El-Centro yang akan diskalakan sesuai skala lokasi pembangunan, $0,25 \mathrm{~g}, 0,50 \mathrm{~g}, 0,75 \mathrm{~g}$ dan $1,00 \mathrm{~g}$. Selain itu mutu beton juga divariasikan menjadi 11 mutu beton yang dimulai dari $15 \mathrm{MPa}$ hingga $25 \mathrm{MPa}$ untuk proses pelatihan jaringan saraf tiruan agar dapat memprediksi tingkat kinerja struktur bangunan gedung kantor. Hasil dari penelitian ini pada analisis tingkat kinerja sesuai dengan analisis riwayat waktu dengan gempa yang diskalakan pada lokasi pembangunan adalah $S A V E$ atau sangat aman dikarenakan daerah pembangunan merupakan daerah tidak rawan gempa, sedangkan hasil pelatihan JST menghasilkan nilai $\mathrm{R}^{2}$ sebesar $98,11 \%$ dan MSE 0,00025 yang berarti pelatihan JST memiliki tingkat kesalahan sangat kecil dan keterkaitan tiap unsur pelatihan sangat bagus. Hasil dari testing JST mendapatkan nilai $\mathrm{R}^{2}$ sebesar 94,59\% dengan nilai MSE 0,00082 yang berarti JST memiliki tingkat validitas tinggi dengan tingkat kesalahan sangat kecil yang hampir mendekati 0 (nol).
\end{abstract}

Kata Kunci : $\quad$ Bangunan Tingkat Rendah, FEMA 356, Tingkat Kinerja 


\begin{abstract}
Earthquakes are unpredictable natural phenomena, when and where they will occur, this natural phenomenon becomes one of the major destructive factors for the areas through which the fault lines pass. The losses caused by the earthquake are huge, ranging from damage to infrastructure, economic and also many casualties. This research will be conducted using Time History Analysis with the help of Finite Element software. Modeling based on building structures built in 2014, and FEMA 356 structural level performance standards. The selection of this building because its seismicity structural analisys is not planned. Capacities classified as El-Centro earthquakes will be scaled according to the construction site scale, 0,25 g, 0,50 g, 0,75 $g$ and 1,00 $\mathrm{g}$. In addition, the quality of concrete is also varied to 11 concrete quality starting from $15 \mathrm{MPa}$ to $25 \mathrm{MPa}$ for the training of Artificial Neural Network so that can be measured the performance level of office building structure. The results of this study with scores corresponding to the earthquake being updated at high speed. The range of earthquakes, while the results of training ANN produced $R^{2}$ value of $98,11 \%$ and MSE 0, 00025 which means the training of ANN has a very small error rate and the relevance of each element of training is very good. The result of the ANN test of $R^{2}$ is 94,59\% with the value of MSE 0,00082 which means the ANN has a high validity level with a very small error rate that is almost close to 0 (zero).
\end{abstract}

Keywords : Low Level Building, FEMA 356, Performance Level

\section{A. PENDAHULUAN}

Pada hakikatnya dalam
perencanaan suatu pembangunan gedung dengan lantai lebih dari satu, harus memiliki dokumen analisis struktur sebagai faktor pendukung perencanaan agar dapat dilaksanakan sampai tahap pembangunan fisik. Di Bangkinang beberapa perencanaan gedung lantai lebih dari satu harus melampirkan dokumen atau laporan analisis struktur beberapa yang lain tidak, namun analisis ini hanya sebatas analisis menggunakan beban mati atau berat sendiri struktur tanpa diikuti pembebanan yang diakibatkan gempa. Dalam wawancara singkat dengan salah satu perencana di Bangkinang, bangunan dua lantai tidak harus menggunakan gempa sebagai beban yang akan diterima stuktur karena intensitas gempa di Kampar tidak sesering Sumatera Barat yang merupakan wilayah rawan gempa. Penelitian ini akan dilakukan analisis struktur dengan menggunakan analisis riwayat waktu (time history) dengan bantuan software elemen hingga dengan beban gempa El Centro dengan 5 (lima) skala berbeda. Pemodelan berdasarkan struktur bangunan gedung kantor yang direncanakan pada tahun pada tahun 2014. Pemilihan perencanaan gedung ini dikarenakan perencanaan tersebut tidak memperhitungkan beban gempa dalam analisis strukturnya.

Penelitian ini juga akan menerapkan ilmu Jaringan Saraf Tiruan (JST) sebagai metode untuk memprediksi tingkat kinerja struktur jika perencanaan menggunakan variasi mutu beton yang berbeda dan skala gempa yang berbeda pula. Diharapkan dengan hasil prediksi, perencanaan ini bisa diterapkan dimanapun lokasi pembangunan, berapapun mutu beton dan berapa besar skala gempa di lokasi tersebut.

Tujuan dari penelitian ini ingin mengetahui tingkat akurasi JST dalam 
memprediksi tingkat kinerja struktur bangunan sesuai dengan input yang sudah ditentukan.

\section{B. TINJAUAN PUSTAKA}

\section{Gempa Bumi}

Gempa bumi terjadi karena fenomena getaran dengan kejutan pada kerak bumi (Schodek D.L., 1999). Gempa bumi merupakan getaran yang terjadi pada oermukaan tanah yang dapat disebabkan oleh aktivitas tektonik, vulkanisme, longsoran termasuk batu batu ataupun bahan peledak (Chen W.F., Lui E.M.,, 2006).

\section{ASCE 41-13}

Analisis riwayat waktu merupakan suatu cara analisa struktur, dimana suatu model matematik dari struktur dikarenakan riwayat waktu dari gempagempa hasil pencacatan atau gempagempa tiruan terhadap riwayat waktu dari respon struktur ditentukan. Proses ini akan mengacu pada SNI 1726-2012 dan FEMA 356.

Sebelum menganalisis riwayat waktu, terlebih dahulu harus melakukan peng-skalaan gempa, perhitungkan percepatan tanah puncak yang disesuaikan dengan pengaruh klasifikasi situs $\left(\mathrm{PGA}_{\mathrm{m}}\right)$ dengan persamaan yang ditetapkan SNI 1726-2012 :

$\mathrm{PGA}_{\mathrm{M}}=\mathrm{F}_{\mathrm{PGA}} \times \mathrm{PGA}$

Dengan :

$$
\begin{aligned}
& \text { PGA }_{M}= \begin{array}{l}
\text { Percepatan tanah puncak } \\
\text { yang disesuaikan dengan }
\end{array} \\
& \text { pengaruh klasifikasi situs } \\
& \text { PGA }= \begin{array}{l}
\text { Percepatan tanah puncak } \\
\text { terpetakan }
\end{array} \\
& \mathrm{F}_{\text {PGA }}= \begin{array}{l}
\text { Koefisien Situs dari tabel } \\
\end{array} \\
& 8 \text { pada SNI 1726-2012 }
\end{aligned}
$$

Setelah nilai $\mathrm{PGA}_{\mathrm{M}}$ diperoleh, kemudian hitung nilai faktor skala riwayat gempa lokasi pembangunan sesuai nilai $\mathrm{PGA}_{\mathrm{M}}$ dengan faktor keutamaan gempa (I) dan koefisien modifikasi respon (R) dengan persamaan :

$\mathrm{PGA}_{\mathrm{M}}($ diskalakan $)=\mathrm{PGA}_{\mathrm{M}}\left(\frac{\mathrm{I}}{\mathrm{R}}\right)$

Dengan :
I = Nilai faktor keutamaan gempa diperoleh dari tabel 2 pada SNI 1726-2012
$\mathrm{R}=$ Nilai koefisien modifikasi respon diperoleh dari tabel 9 pada SNI 1726-2012

\section{Tingkat Kinerja (Performance Levels)}

FEMA 356 menjelaskan tingkat kinerja secara berturut-turut dari respon paling kecil, terdiri atas:

a. Fully Operational (FO) adalah kondisi yang mana bangunan tetap dapat beroperasi langsung setelah gempa terjadi.

b. Immediate Occupancy (IO) adalah kondisi yang mana struktur secara umum masih aman untuk kegiatan operasional segera setalah gempa terjadi.

c. Life Safety (LS) adalah suatu kondisi yang mana struktur bangunan mengalami kerusakan sedang, sehingga diperlukan perbaikan, namun bangunan masih stabil dan mampu melindungi pemakai dengan baik.

d. Collapse Prevention (CP) adalah suatu kondisi yang mana struktur bangunan mengalami kerusakan parah, pada kondisi ini bangunan sudah tidak dapat dipakai lagi.

Sasaran penting dari analisis berbasis kinerja bangunan terhadap gempa dinyatakan secara jelas. Sasaran kinerja terdiri dari kejadian gempa 
rencana yang ditentukan (Earthquake Hazard), dan taraf kerusakan yang diijinkan atau tingkat kinerja dari bangunan terhadap kejadian gempa tersebut. Pertimbangan perencanaan bangunan terhadap resiko gempa dapat dilakukan dengan menerapkan prinsip berikut :

a. Gempa ringan, bangunan tidak boleh rusak secara struktural dan arsitektural.

b. Gempa sedang, komponen struktural (balok dan kolom) tidak diperbolehkan rusak sama sekali tetapi komponen arsitektural diperbolehkan.

c. Gempa berat, boleh terjadi kerusakan pada komponen struktural tetapi tidak menyebabkan keruntuhan bangunan.

\section{Jaringan Saraf Tiruan (JST)}

Ilmu mengenai sel saraf biologi didalam otak telah memberikan ide dalam pengembangan sistem komputerisasi yang saat ini di kenal dengan Jaringan Saraf Tiruan (JST). Susunan dan operasi JST dapat digambarkan dalam bentuk model matematis dan simulasi dari model saraf biologi. Dilihat dari fungsi, JST diciptakan untuk merancang sistem komputerisasi yang dapat difungsikan untuk melakukan proses belajar dari suatu contoh kejadian.

Sedangkan dari struktur rancangan, JST merupakan suatu alat hitung yang ditujukan untuk dapat melakukan sesuatu yang serupa dengan cara kerja jaringan biologi otak manusia. Otak manusia memiliki jaringan saraf yang terdiri dari beberapa neuron yang mempunyai hubungan antara satu dengan yang lainnya.

Algoritma penelitian ini menggunakan algoritma Backpropagation yang mana pelatihan ini pertama kali dirumuskan oleh
Werbis dan dipopulerkan oleh Rumelhart dan McClellan. Pembelajaran algoritma ini adalah pembelajaran yang terawasi dan biasanya digunakan oleh perceptron dengan banyak lapisan untuk mengubah bobot-bobot yang terhubung dengan neuron-neuron yang ada pada lapisan tersembunyi. Jaringan ini terdiri dari satu input layer, satu output layer dan satu atau lebih hidden layer yang dapat ditentukan oleh orang merancang JST tersebut (Zhao dkk., 1998). Arsitektur jaringan algoritma ini memiliki 3 (tiga) lapisan yang terdiri dari input, hidden, dan output.

Secara garis besar dapat dideskripsikan, ketika jaringan diberikan pola masukan sebagai pola pelatihan maka pola tersebut menuju unit-unit lapisan tersembunyi untuk diteruskan ke unit-unit lapisan keluaran. Setelah proses tersebut unit-unit lapisan keluaran memberikan tanggapan yang disebut dengan keluaran jaringan, saat keluaran jaringan tidak menghasilkan keluaran yang sesuai dengan apa yang diharapkan maka akan menyebar mundur pada lapisan tersebunyi dan diteruskan ke unit lapisan masukan. Oleh sebab itu maka mekanisme ini disebut pelatihan propagasi balik (backpropagation).

JST yang sudah dirancang kemudian diperiksa tingkat kesalahan dan tingkat validitas untuk menilai keakuratan hasil prediksi JST tersebut. Tingkat kesalahan JST dinyatakan dalam Mean Squared Errors (MSE) yang dapat dihitung dengan persamaan berikut :

$$
\operatorname{MSE} \quad=0,5\left(\mathrm{~T}_{\mathrm{k}} / \mathrm{Y}_{\mathrm{k}}\right)^{2}
$$

Jika nilai MSE mendekati 0 (nol) maka dalam melakukan prediksi, JST memiliki tingkat kesalahan yang kecil yang berarti JST dapat digunakan jika 
nilai $R^{2}$ mendekati nilai 1 . Nilai $R^{2}$ dihitung menggunakan persamaan berikut :

$$
\mathrm{R}^{2}=1-\left[\frac{\sum_{\mathrm{k}}^{\mathrm{n}}\left(\mathrm{T}_{\mathrm{k}}-\mathrm{Y}_{\mathrm{k}}\right)^{2}}{\sum_{\mathrm{k}}^{\mathrm{n}}\left(\mathrm{T}_{\mathrm{k}}-\mathrm{T}_{\mathrm{avg}}\right)^{2}}\right]
$$

\section{DATA DAN ANALISA DATA \\ 1. Data Struktur}

Pemodelan struktur gedung mengacu pada satu perencanaan pembangunan gedung perkantoran 2 lantai di Bangkinang dengan panjang gedung $28 \mathrm{~m}$ dan lebar gedung $16 \mathrm{~m}$. Tinggi perlantai $3,6 \mathrm{~m}$. Mutu tulangan yang digunakan pada perencanaan tersebut adalah $240 \mathrm{MPa}$. Dimensi elemen struktur yang digunakan adalah sebagai berikut:
a. Kolom type-K1 40x40 $\mathrm{cm}^{2}$
b. Kolom type-K2 $30 \times 60 \mathrm{~cm}^{2}$
c. Balok type-B1 $20 \times 40 \mathrm{~cm}^{2}$
d. Balok type-B2 25/50 $\mathrm{cm}^{2}$

Variasi mutu beton yang akan digunakan dapat dilihat pada tabel 1 .

Tabel 1. Tabel Variasi Mutu Beton

\begin{tabular}{ccccc}
\hline No & $\begin{array}{c}\text { Mutu Beton } \\
(\mathbf{M P a})\end{array}$ & $\begin{array}{c}\text { Poisson's } \\
\text { Ratio Beton }\end{array}$ & $\begin{array}{c}\text { Modulus Elastisitas } \\
(\mathbf{M P a})\end{array}$ & $\begin{array}{c}\text { Berat Jenis } \\
\left(\mathbf{K g} / \mathbf{m}^{\mathbf{3}}\right)\end{array}$ \\
\hline 1 & 15 & 0,2 & 18203,02 & 2400 \\
2 & 16 & 0,2 & 18800,00 & 2400 \\
3 & 17 & 0,2 & 19378,60 & 2400 \\
4 & 18 & 0,2 & 19940,41 & 2400 \\
5 & 19 & 0,2 & 20486,83 & 2400 \\
6 & 20 & 0,2 & 21019,04 & 2400 \\
7 & 21 & 0,2 & 21538,11 & 2400 \\
8 & 22 & 0,2 & 22044,95 & 2400 \\
9 & 24 & 0,2 & 23025,02 & 2400 \\
10 & 25 & 0,2 & 23500,00 & 2400 \\
\hline
\end{tabular}

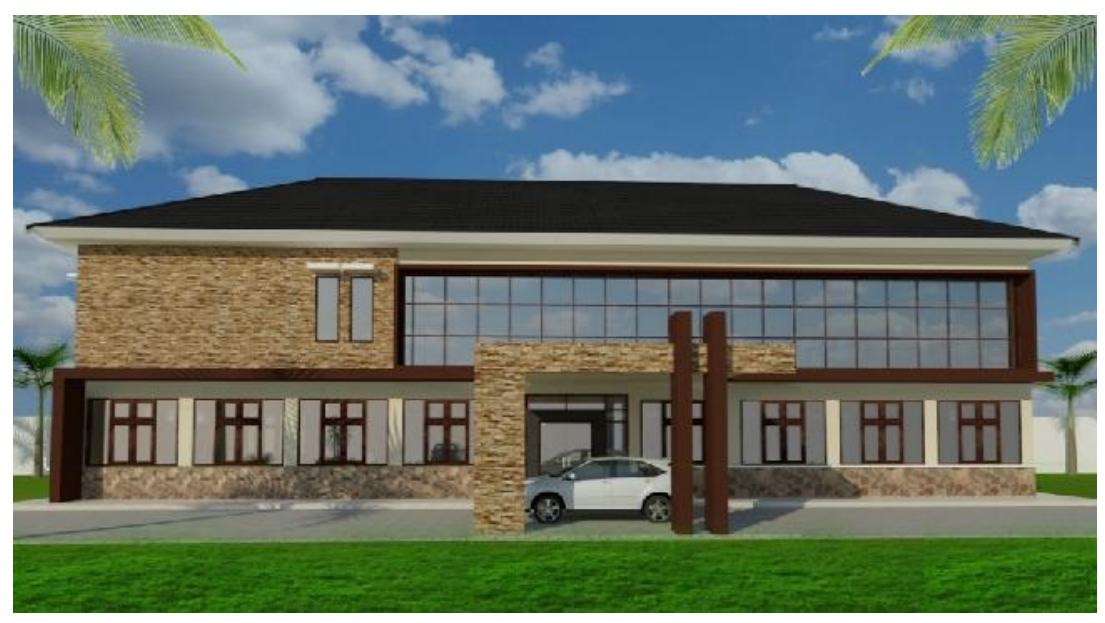

Gambar 1. Gedung Perkantoran Kabupaten Kampar 


\section{Data Beban}

Berdasarkan PPUIG (1987), pembebanan pada gedung terdiri dari beban mati, beban hidup dan beban gempa. Berikut beban-beban yang bekerja pada bangunan gedung kantor yang dimodelkan yaitu :

a. Beban mati

1). Bekerja pada pelat lantai terdiri atas berat spesi keramik, berat keramik, berat plafond dan berat mekanikal elektrikal yang total keseluruhannya adalah $74 \mathrm{Kg} / \mathrm{m}^{2}$

2). Bekerja pada pelat atap terdiri atas berat plafond dan berat mekanikal elektrikal, total keseluruhannya adalah $30 \mathrm{Kg} / \mathrm{m}^{2}$

3). Bekerja pada balok yang menahan berat dinding sebesar $80 \mathrm{Kg} / \mathrm{m}^{2}$

b. Beban hidup

1). Bekerja pada pelat lantai untuk gedung perkantoran ditetapkan oleh PPIUG sebesar $250 \mathrm{Kg} / \mathrm{m}^{2}$

2). Bekerja pada pelat atap 100 $\mathrm{Kg} / \mathrm{m}^{2}$

c. Beban gempa

Beban gempa yang digunakan berupa catatan respon riwayat waktu (time history) yang penyesuaian skala ditentukan berdasarkan standar perencanaan ketahanan gempa Indonesia dengan kondisi situs tanah sedang. Data gempa untuk penelitian ini adalah gempa El-Centro dengan 5 variasi skala yaitu skala kelas situs lokasi pembangunan, $0,25 \mathrm{~g}, 0,5 \mathrm{~g}$, $0,75 \mathrm{~g}$, dan $1,00 \mathrm{~g}$.

Lokasi pembangunan gedung kantor terletak pada bujur $0,31966^{\circ}$, lintang $101,03245^{\circ}$ yang nilai PGA lokasi tersebut adalah 0,076g. Sesuai dengan tabel 8 pada SNI 1726-2012 maka :

$$
\begin{aligned}
\mathrm{F}_{\mathrm{PGA}} & =1,6 \\
\mathrm{PGA}_{\mathrm{M}} & =\mathrm{F}_{\mathrm{PGA}} \times \mathrm{PGA} \\
& =1,6(0,076) \\
& =0,1215 \mathrm{~g}
\end{aligned}
$$

$$
\begin{aligned}
\operatorname{PGA}_{M}(\text { diskalaka }) & =\operatorname{PGA}_{M}(\mathrm{I} / \mathrm{R}) \\
& =0,1216(1 / 5) \\
& =0,02432 \mathrm{~g}
\end{aligned}
$$

Jadi skala gempa El-Centro pada lokasi rencana pembangunan yang akan digunakan untuk analisis riwayat waktu adalah $0,02432 \mathrm{~g}$.

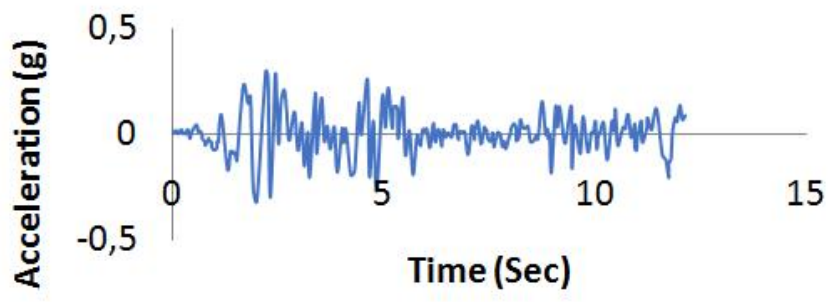

Gambar 2. Riwayat Waktu Gempa El-Centro

\section{Tahapan Analisis Riwayat Waktu}

Berikut penjelasan tahapan analisis dengan bantuan software elemen hingga : a. Modelkan struktur dengan data material dan dimensi sesuai dengan data struktur yang sudah terencana. Pemodelan diikuti dengan mendefinisikan material yang digunakan struktur dan setiap elemen 
yang dimulai dari balok, kolom, pelat lantai dan pelat atap.

b. Masukkan beban sesuai dengan data beban mati dan beban hidup dilanjutkan ke tahap run analisis model struktur untuk melihat analisis ragam akibat beban sendiri.

c. Defenisikan data gempa El-Centro sebagai data time history dimulai dari skala situs lokasi pembangunan. Kemudian defenisikan kasus pembebanan beban mati menjadi nonlinear.

d. Defenisikan nilai sendi plastis sesuai dengan FEMA 356

e. Lakukan analisis perilaku struktur dari hasil analisis riwayat waktu berupa perpindahan, kecepatan dan percepatan.

f. Lihat tingkat kinerja stuktur yang diakibatkan beban gempa yang berdasarkan riwayat waktu.

g. Lakukan tahapan a hingga $f$ dengan variasi skala gempa $0,25 \mathrm{~g}, 0,50 \mathrm{~g}$, $0,75 \mathrm{~g}$, dan $1,00 \mathrm{~g}$ dan juga dengan variasi mutu beton.

\section{Tahapan Pelatihan JST}

Analisis tingkatan kerusakan struktur pada gedung 2 (dua) lantai ini menggunakan metode JST dengan jenis arsitektur jaringan lapisan banyak backpropogation. Parameter yang dipilih sebagai input adalah mutu beton (fc'), respon struktur tersebut yang berupa perpindahan, kecepatan dan percepatan struktur. Sementara parameter output yang akan diprediksi adalah tingkat kinerja struktur dalam kategori Safe, Immediate Occupancy (IO), Life Safety (LS) atau dalam kondisi Collapse Prevention (CP). Proses prediksi dengan metode jaringan saraf tiruan ini menggunakan bantuan program MATLAB.
Arsitektur jaringan dan fungsi aktivasi serta jumlah lapisan hidden layer dapat ditentukan di program ini. Dari data analisis riwayat waktu, digunakan data pelatihan JST berupa hasil analisis riwayat waktu menggunakan mutu beton $15 \mathrm{MPa}$ hingga $24 \mathrm{MPa}$, sedangkan mutu beton $25 \mathrm{MPa}$ digunakan untuk pengujian JST. Arsitektur jaringan menggunakan jaringan lapisan banyak backpropogation dengan 1 input layer terdiri dari 10 neuron (mutu beton, perpindahan, kecepatan dan percepatan pada arah $\mathrm{x}, \mathrm{y}$, dan $\mathrm{z}$ ), 1 hidden layer dengan 21 neuron, dan 1 output layer dengan 4 neuron.

Untuk output yang berupa kategori Safe, Immediate Occupancy (IO), Life Safety (LS) atau dalam kondisi Collapse Prevention (CP) didefenisikan ke dalam MATLAB sebagai data terget prediksi. Safe yang merupakan keadaan untuk kategori kerusakan mulai dari tahap awal sampai pada tahap B diberi kode 1, Immediate Occupancy (IO) diberi kode 2, Life Safety (LS) diberi kode 3 dan Collapse Prevention (CP) diberi kode 4 .

\section{HASIL DAN PEMBAHASAN}

Jaringan saraf tiruan yang dibuat memiliki input perpindahan, kecepatan, dan percepatan yang ditinjau dari arah X, Y dan Z. Hasil atau output yang akan dihasilkan dari JST yang dibuat adalah tingkat kinerja struktur yang dikategorikan Safe, IO, LS dan CP. Pada proses pelatihan JST dilakukan pada model struktur dengan mutu beton $15 \mathrm{MPa}$ hingga $24 \mathrm{MPa}$ yang dibebani oleh gempa El-Centro dengan 5 skala, dari pelatihan tersebut didapat nilai MSE 0,0019219 seperti yang ditunjukan oleh gambar 3 yang mana nilai MSE mendekati 0 . 


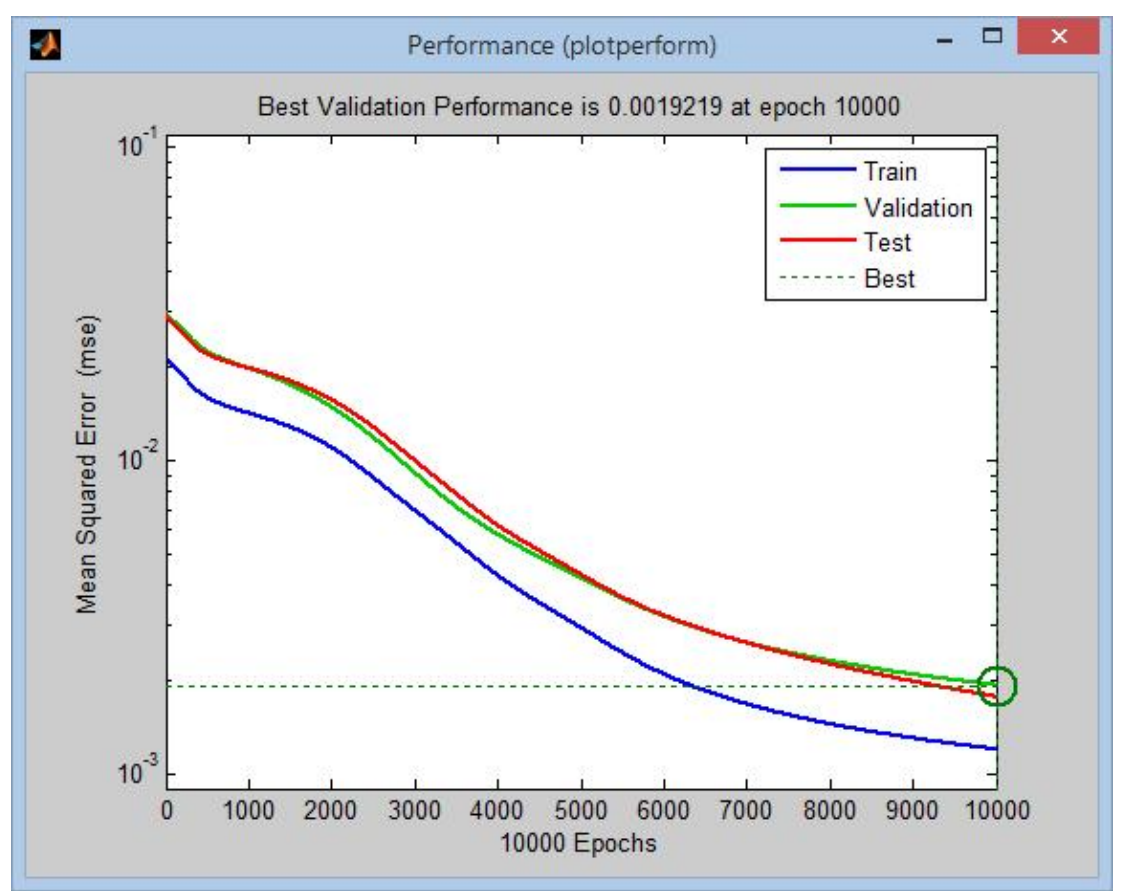

Gambar 3. MSE Jaringan Saraf Tiruan

Pada Gambar 4 di peroleh nilai $\mathrm{R}$ untuk JST sebesar 0,97476 yang berarti hasil prediksi memiliki tingkat validasi tinggi yang mana nilai $\mathrm{R}$ mendekati 1 . Maka dapat disimpulkan JST memiliki tingkat prediksi tinggi.

Setelah proses pelatihan JST dilakukan disimpulkan JST dapat digunakan untuk memprediksi tingkat kinerja karena nilai MSE 0,0019219 dan nilai $\mathrm{R}$ 0,97476. Dikarenakan JST memiliki tingkat kesalahan rendah dan validitas tinggi, maka JST yang sudah dirancang bisa digunakan ketahap testing atau uji coba untuk memprediksi tingkat kinerja.

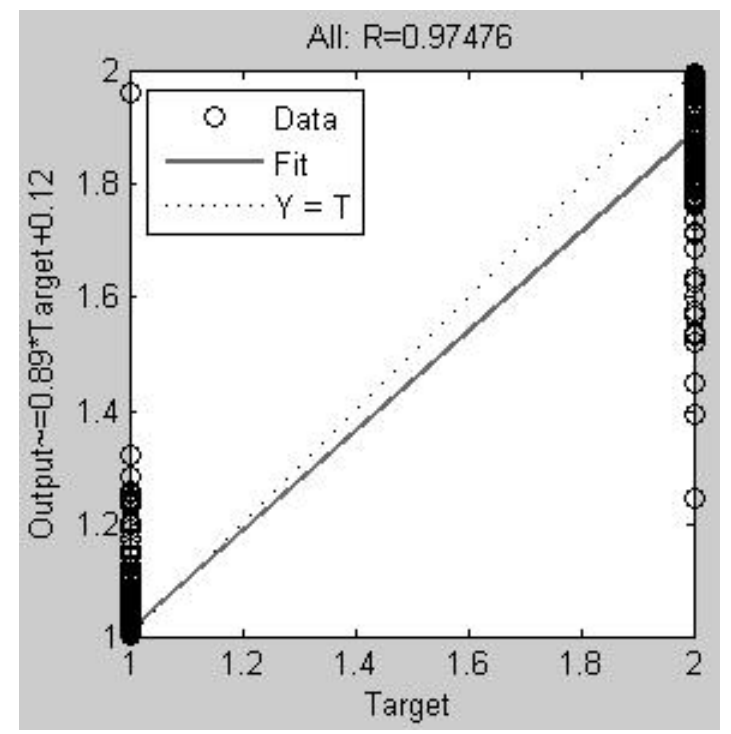

Gambar 4. Grafik R untuk Jaringan Saraf Tiruan 
Tabel 2.Pemeriksaan Hasil Prediksi JST

\begin{tabular}{|c|c|c|c|c|c|c|c|c|}
\hline \multirow{2}{*}{ No. } & \multirow{2}{*}{ Riwayat Waktu } & \multirow{2}{*}{$\begin{array}{l}\text { Waktu } \\
\text { (Detik) }\end{array}$} & \multicolumn{2}{|c|}{ Output } & \multirow{2}{*}{$\begin{array}{c}\text { Prediksi } \\
\text { Training } \\
(Y k)\end{array}$} & \multirow{2}{*}{$\begin{array}{l}\text { Target - Prediksi } \\
\qquad\left(T_{k}-Y_{K}\right)^{2}\end{array}$} & \multirow{2}{*}{$\begin{array}{c}\text { Target - Nilai } \\
\text { Rata* }^{*}\left(T_{\kappa}-T_{\text {avg }}\right)^{2}\end{array}$} & \multirow{2}{*}{$M S E=0,5 \times\left(T_{k}-Y_{k}\right)^{2}$} \\
\hline & & & Target (Tk) & Kategori & & & & \\
\hline 1 & El Centro - $0,024 \mathrm{~g}$ & 0,00 & 1 & SAFE & 1 & 0,00000000000 & 0,00097 & 0,0000000000000 \\
\hline 2 & El Centro $-0,024 \mathrm{~g}$ & 0,05 & 1 & SAFE & 1 & 0,00000000000 & 0,00097 & 0,0000000000000 \\
\hline 3 & El Centro - $0,024 \mathrm{~g}$ & 0,10 & 1 & SAFE & 1 & 0,00000000000 & 0,00097 & 0,0000000000000 \\
\hline 4 & El Centro - 0,024g & 0,15 & 1 & SAFE & 1 & 0,00000000000 & 0,00097 & 0,0000000000000 \\
\hline 5 & El Centro - 0,024g & 0,20 & 1 & SAFE & 1 & 0,00000000000 & 0,00097 & 0,0000000000000 \\
\hline 6 & El Centro $-0,024 \mathrm{~g}$ & 0,25 & 1 & SAFE & 1 & 0,00000000000 & 0,00097 & 0,0000000000000 \\
\hline 7 & El Centro $-0,024 \mathrm{~g}$ & 0,30 & 1 & SAFE & 1 & 0,00000000000 & 0,00097 & 0,0000000000000 \\
\hline 8 & El Centro - 0,024g & 0,35 & 1 & SAFE & 1 & 0,00000000000 & 0,00097 & 0,0000000000000 \\
\hline 9 & El Centro $-0,024 \mathrm{~g}$ & 0,40 & 1 & SAFE & 1 & 0,00000000000 & 0,00097 & 0,0000000000000 \\
\hline 10 & El Centro - 0,024g & 0,45 & 1 & SAFE & 1 & 0,00000000000 & 0,00097 & 0,0000000000000 \\
\hline - & $\cdot$ & $\cdot$ & $\cdot$ & $\cdot$ & - & - & - & - \\
\hline - & $\cdot$ & - & $\cdot$ & - & $\cdot$ & - & - & - \\
\hline$\dot{602}$ & El Centro- $1,00 \mathrm{~g}$ & 1,50 & $\dot{2}$ & IO & $1, \dot{9998}$ & 0,00000004000 & $0,9 \dot{3} 858$ & 0,0000000200000 \\
\hline 603 & El Centro $-1,00 \mathrm{~g}$ & 1,55 & 2 & 10 & 1,9994 & 0,00000036000 & 0,93858 & 0,0000001800000 \\
\hline 604 & El Centro - 1,00g & 1,60 & 2 & 10 & 1,9996 & 0,00000016000 & 0,93858 & 0,0000000800000 \\
\hline 605 & El Centro - 1,00g & 1,65 & 2 & 10 & 1,9999 & 0,00000001000 & 0,93858 & 0,0000000050000 \\
\hline 606 & El Centro - 1,00g & 1,70 & 2 & 10 & 1,9998 & 0,00000004000 & 0,93858 & 0,0000000200000 \\
\hline 607 & El Centro - 1,00g & 1,75 & 2 & 10 & 2 & 0,00000000000 & 0,93858 & 0,0000000000000 \\
\hline 608 & El Centro - $1,00 \mathrm{~g}$ & 1,80 & 2 & 10 & 2 & 0,00000000000 & 0,93858 & 0,0000000000000 \\
\hline 609 & El Centro $-1,00 \mathrm{~g}$ & 1,85 & 2 & 10 & 2 & 0,00000000000 & 0,93858 & 0,0000000000000 \\
\hline \multicolumn{3}{|c|}{ Nilai Rata-rata Target $\left(\mathrm{T}_{\mathrm{avg}}\right)$} & 1,03120 & & & & & \\
\hline \multicolumn{3}{|c|}{ MSE } & & & & & & 0,00082 \\
\hline \multicolumn{3}{|c|}{$\sum_{k}^{n}\left(T_{k}-Y_{k}\right)^{2}$} & & & & 0,99537 & & \\
\hline \multicolumn{3}{|c|}{$\sum_{k}^{n}\left(T_{k}-T_{a v g}\right)^{2}$} & & & & & 18,40722 & \\
\hline \multicolumn{3}{|c|}{$R^{2}=1-\left[\frac{\sum_{k}^{n}\left(T_{k}-Y_{k}\right)^{2}}{\sum_{k}^{n}\left(T_{k}-T_{\text {avg }}\right)^{2}}\right]$} & & & & \multicolumn{2}{|c|}{0,94592} & \\
\hline
\end{tabular}

Saat pemeriksaan dari hasil prediksi testing JST didapat nilai $\mathrm{R}^{2}$ 0,94592 dengan nilai MSE 0,00082. Hasil uji coba ini memiliki tingkat kesalahan sangat kecil dan tingkat validitas sangat bagus, dapat disimpulkan JST sangat akurat dalam melakukan prediksi tingkat kinerja struktur bangunan gedung kantor 2 lantai.

\section{E. KESIMPULAN}

Dari hasil analisis riwayat waktu dan prediksi JST pada penelitian ini dapat disimpulkan :

1. Hasil pelatihan JST dengan total data pelatihan ini sebanyak 6054 data yang diperoleh dari model struktur menggunakan 10 mutu beton (15 $\mathrm{MPa}$ hingga $24 \mathrm{MPa}$ ) yang dianalisis menggunakan sistem fungsi riwayat waktu gempa El-centro (5 skala), memiliki nilai MSE 0,0019219 dan R 0,97476. Berarti JST yang sudah dirancang memiliki tingkat prediksi yang akurat.

2. Hasil uji coba JST dalam memprediksi tingkat kinerja model struktur gedung kantor 2 lantai dengan mutu beton $25 \mathrm{MPa}$, menunjukkan tingkat kesesuaian yang tinggi dengan nilai $\mathrm{R} 0,94592$ dan tingkat kesalahan yang sangat rendah dengan nilai MSE 0,00082. 


\section{DAFTAR PUSTAKA}

Departemen Pekerjaan Umum, 1987, Pedoman Pembebanan Untuk Rumah dan Gedung, Yayasan Badan Penerbit PU, Jakarta.

Badan Standarisasi Nasional, 2012, Tata Cara Perencanaan Ketahanan Gempa Untuk Struktur Bangunan Gedung dan
Non Gedung SNI-1726-2012, $B S N$, Bandung.

Zhao J., Iven J., DeWolf J., 1998, Structural Demage Detection Using Artificial Neural Networks, Retrieved From : http://doi.org/10.1109/CIMSA.20 12.6269593 . 